\title{
Research on Project Construction Cost Major Talent Training Mode Based on Management Science and Engineering
}

\author{
Yin Yang \\ School of Accounting \\ Wuhan Textile University \\ Wuhan, China \\ cs_yangyin@hust.edu.cn \\ Lifeng Zhang \\ School of Accounting \\ Wuhan Textile University \\ Wuhan, China \\ 2008069@wtu.edu.cn
}

\author{
Tong Xu \\ School of Accounting \\ Wuhan Textile University \\ Wuhan, China \\ xssunt123@gmail.com \\ Zongxin Gong \\ School of Accounting \\ Wuhan Textile University \\ Wuhan, China \\ gzx199561@163.com
}

\begin{abstract}
The project construction cost personnel distributes in different fields related to the basic construction of the government, construction unit and design units. They play a crucial role in the engineering investment control and investment goals, as well as the determination of reasonable project construction cost and effective control of project construction cost. This paper integrated the characteristics of management science and engineering and the project construction cost, researching the system of project construction cost major teaching cultivation based on the management science and engineering, the practice of teaching system and innovative talent training system, which explores a feasible way for engineering cost major talent training based on the management science and engineering.
\end{abstract}

Keywords-project construction cost; teaching training; practice training; talent training

\section{INTRODUCTION}

With the rapid increasing the number of capital construction and larger investment, decision-making, design, bidding and construction cost control management and technology talents demand in the process of engineering construction also increase quickly. Establishing and improving based on the management science and engineering to adapt to the market demand of the project construction cost major talent-training mode. We cultivate a batch of compound and applied talents who both know engineering and civil technology and understand the relevant accounting and economic knowledge, which can be engaged in the whole process project construction cost valuation. In order to meet the growing senior project construction cost management talent demand of project construction cost determination and control, which is an urgent problem to solve in the project construction cost characteristics professional talent training scheme and model [1].

Universities can push and organize the science and technology innovation [2]. At the same time, the innovation of science and technology development cannot be without the talents construction, so the burden of training talents falls upon colleges and universities. Therefore, the sustainable development of science and technology and innovation system, various colleges and universities must improve the innovation of education concept, further straightening out the innovative talent training system, developing various mode of innovative talents cultivation plan, standardizing the university talent training system construction, which is the foundation to achieve long term sustainable development of science and technology.

There are two kinds of education pattern of project construction cost major: relying on a professional basis of science and technology for the implementation stage of the cost management (civil). Relying on the foundation of the management, economy, finance, audit and other subjects, this focuses on the ends business of the whole process cost management (management science and engineering) [3]. The highlight basic management theoretical knowledge of engineering cost major and the practical cost teaching is essential content under the background of management science, which is also the key content of this study.

\section{The Whole Process Cost Management Server of PROJECT CONSTRUCTION COST MAJOR}

Under the management science and engineering, the project construction cost major in the cultivation concept that "market-oriented, cultivating high-quality applied talents with high diathesis," which is based on management, economics, 
accounting, auditing and other management science and engineering advantage. The project construction cost major outstands comprehensive and professional cross subjects, to meet market demand and qualification and capacity requirements as the guidance, training comprehensive innovative talents in line with the whole process cost management fields. We integrate characteristics of the major orientation both at domestic and abroad, relying on the advantage of management, accounting, auditing, and other subjects under the background of management science and engineering, in early project trading period and late cost consulting business, cultivating financial advisers who participates the main body of the engineering construction. In order to achieve the project construction cost major graduates to supply the market differentiation [4].

The specific business process of the whole process cost management shown in Fig. 1. The intermediate business of the whole process cost management is traditionally the main source of the civil institute in colleges and higher vocational college of project construction cost major. Therefore, combining with the project construction cost major with management science and engineering, to develop teaching system reform that rely on the base of subjects such as management, accounting and audit of the whole process of cost management in the business with an emphasis on both ends. The bold italics part Fig. 1 is under the background of management science and engineering cost major training direction.

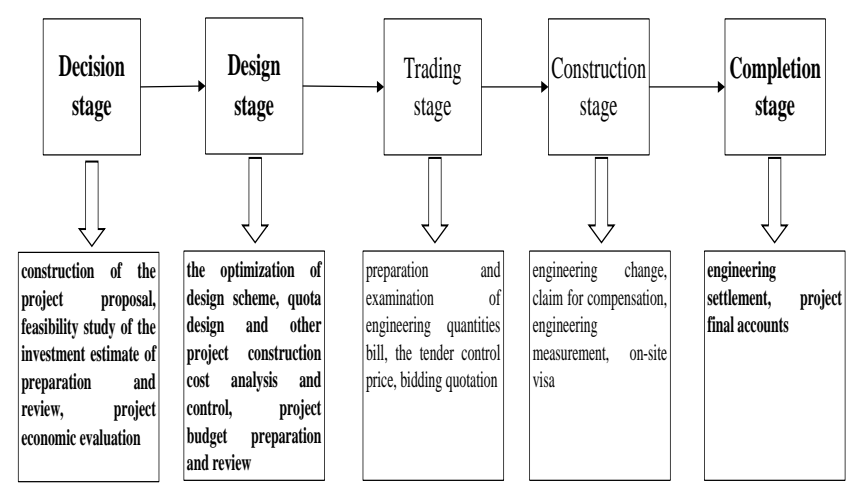

Fig. 1. The specific business process diagrams of project construction cost of the whole process cost management.

\section{The Project Construction Cost Major Teaching TRAINING SYSTEM}

Scopes of certified cost engineers are the specific requirements to develop students' professional ability of project construction cost major, the corresponding knowledge covers the metering technology, valuation technology, contract law, economy, management and accounting aspects of content, training system from the technical platform, management platform, economic platform, legal platform that supports the project construction cost professional platform [5].

Teaching training program of engineering cost major should reflect the market demand based on the management science and engineering, and cover needed basic knowledge structure of teaching training plan required by the cost of registered engineers. In order to implement on the basis of the professional education study and certification, combining with the specific situation of the management science and engineering, which is based on the specific business process of the whole process cost management of the project construction cost major (Fig. 1). Engineering cost major teaching training system based on the management science and engineering includes: general courses platform: The ideological and political platform, English platform, sports platform. Discipline basic course platform: computer basis platform, math platform, accounting basis platform. Professional course platform: science and technology platform, economic management platform, accounting platform, laws and regulations platform, the construction cost platform. The practice teaching platform: social practice platform, curriculum design platform, practice teaching platform, graduation practice platform, and graduation design platform. In this teaching training system, the accounting basis, professional accounting, economic management classes and teaching practice are to highlight the advantages and characteristic of management science and engineering, which includes the main courses: accounting, financial management, economics, auditing, management, project financing, management accounting, assets evaluation, financial analysis, etc.

The building of the teaching training system will explore and practice from the following aspects: first is to build professional curriculum system that is cored on certified cost engineers' vocational ability, highlighting major setting combined with professional standards. Second, in the building of basic curriculum system of construction cost which is cored on engineering technology employment ability, both thinking of the need of sustainable development, highlighting major setting links up with engineering practice? Three is the advantage of the characteristic curriculum system that is cored on management, accounting, auditing, management science and technology, highlighting the match major setting and employment competitiveness.

\section{DEVEloping System OF THE PROJECT CONSTRUCTION Cost MAJOR PRACTICE}

The project construction cost major has a practical feature, so the innovation and construction ability of individual student has been influenced by personal practical ability based on acquiring major professional knowledge. In the practical training process, we should focus on the student which adjusts developing system to the society demand, training purpose, construction of knowledge, and the feature of subject in order to build a various concerning-student teaching training system.

Developing process of the project construction cost major practice under Management Science and construction work shown in Fig. 2. It mainly contains part of social practice, course design, teaching internship, graduate internship and graduate design which all stages practice throughout the whole project construction cost major teaching. The part of social practice and graduate internship concern about construction companies, furthermore internship plays a valuable role in elites developing system which can directly make students 
adapt and theoretical knowledge to specific reality work which deal with the problems about overreaching.

First, being aimed at different companies, this paper makes a suitable appropriate internship plane which includes teaching internship and graduate internship to analyze some problems maybe student would suffer in potential, through practice courses and arrange the specific project construction cost work in apprenticeship sites. In the meantime, some related technological operator as tutor for students, in turn of making sure about available time, design some construction tasks and set up evaluation institution. And these tutors also need to host some defenses about internship to check result of student construction practice, according to the evaluation institution.

Second, courses design and graduate design will be hold in campus and using simulation laboratory to develop the manipulative abilities and Practical skills.

(1) Building the calculating mill. The main task is that how to learn to use 3D-Measuring software to basically divide some construction programs. And understand the difference between fixed pricing and Bill of Quantities, architecture area calculating rule and method of construction capacities calculating. Through simulate calculating to some real architecture models and establish group which contains four to six Students of each one, these groups can set up Cost consulting companies and every student should be in charge of different job in a company. Last, using software, model to evaluate and grade the status of constructions design, calculating from every group.

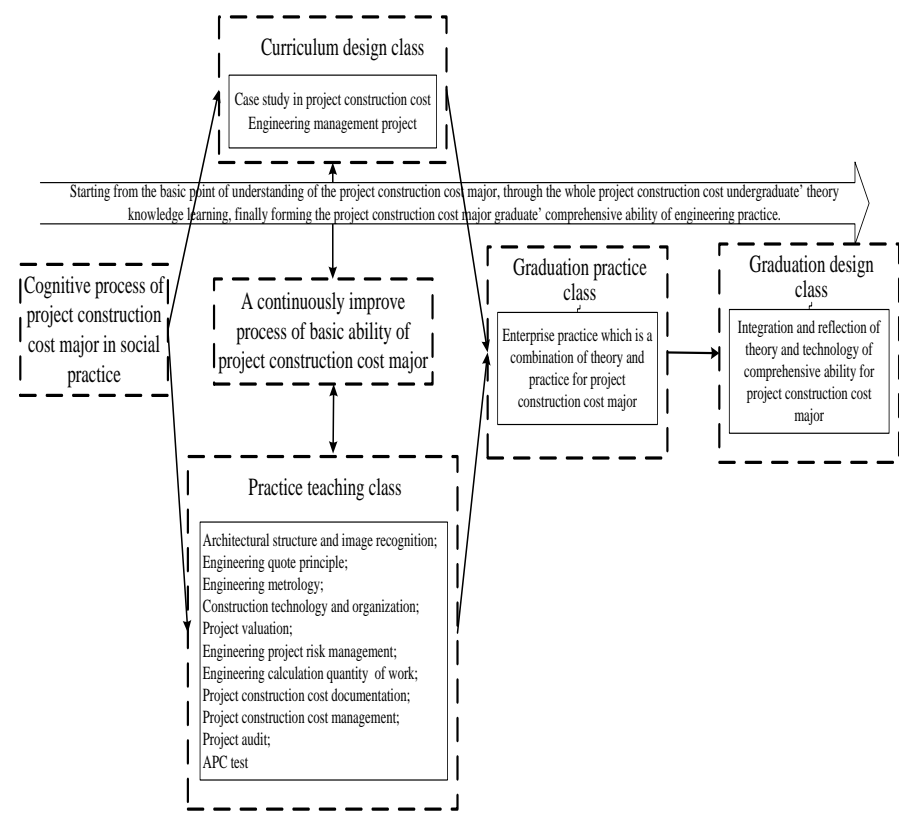

Fig. 2. The project construction cost major practice training based on the management science and engineering.

(2)Building the studio of simulate construction tendering. It can be used in construction tendering and bill of quantity courses or graduate design. In the simulate practices of construction tendering, invite some experts as tutor, adopting role-playing style experiment to completely stimulate the whole processes about beginning of posting invitation for bids to end of posting the bid-winning notification.

(3)Building the APC testing center. Inviting some related staff from Constructor, Builder and Designer, organize the evaluation about professional abilities to make interview for students so that can exam their result of acquiring professional major knowledge. It can make students to learn about the piratical application of project construction cost which not only exam student's knowledge can level but also make student to deeply know about specific work.

(4)Building life cycle project construction cost management studio. All students need to be known all processes of the whole life cycle, and furthermore they should organize knowledge what they had learned in past four years and learn to how to combine knowledge and real work processes. What's more, it can develop the student's abilities about handling basic knowledge and practice of project construction cost knowledge in order to make fundamental work for other learning. In the meanwhile, make students to realize the knowledge feature of project construction cost that based on management subject such as accounting, financial management and auditing.

\section{CREATIVE ELITE TRAINING SYSTEM OF CONSTRUCTION COST MAJOR}

Creative elite system should be based on the basic knowledge of project construction cost major, and insist the principle of learning completely, learning goodly, learning solidly, learning practically, in addition to needing to have potential developing ability [6]. Therefore, the elite training of project construction cost major should combine relevance from some technological courses with complementarities from engineering courses to strength the frame of knowledge. The fundamental ability is still based on courses frame but the practice process is most valuable to show the creative elite training system. Obviously the realistic pricing ability should coalesce basic knowledge with theories from management science. Creative elite training system of construction cost major based on management science and project shown in Fig. 3.

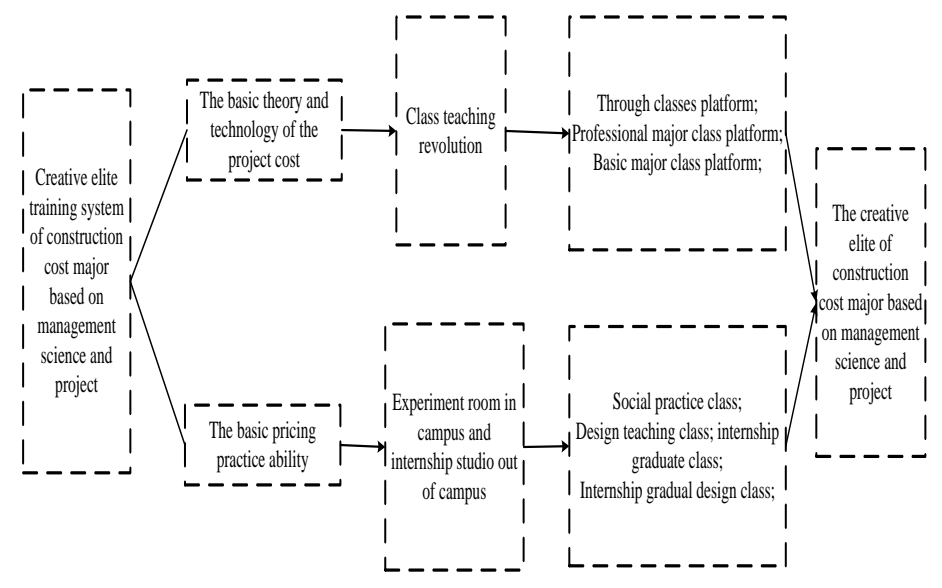

Fig. 3. The creative elite training system of construction cost major based on management science and project. 


\section{SUMMARY}

Building the creative elite training system of construction cost major based on management science and project, need to accord feature of management science and combine the type of project construction cost major. It can concretely define the student's major and adjust the teaching, practice plan and training plans above all of these, this paper purposes major academic teaching training system revolution plan and considers management, accounting, finance, auditing as guide in study or work which can better solve the principle and ideal problems of project construction cost major. Taking insight of management courses and courses internship, combining social work requirement with graduate design, solves the practice problems and issue of training elite manner problem.

\section{ACKNOWLEDGMENT}

This research was financially supported by the 2016 Teaching Research Project of Wuhan Textile University.

\section{REFERENCES}

[1] S. C. Barrie, "A research-based approach to generic graduate attributes policy,” Higher Education Research\&Development, vol.23, pp. 261-275, 2004.

[2] H. J. Wang, et al, "On training of veterinary specific innovative talents in comprehensive," Journal of Southwest China Normal University (Natural Science Edition), vol.41, pp. 164-168, 2016.

[3] J. M. Bots, E. Groenland, and D. M. Swagerman, “An empirical test of birkett's competency model for management accountants: survey evidence from dutch practitioners,” Journal of Accounting Education, vol.27, pp. 1-13, 2009.

[4] K. Zehetner, B. Fahrngruber, R. Pichler, and S. Trappl, "Financial leadership-transforming financial experts, International Journal of Business and Management Studies,” vol.2, pp. 615- 621, 2013.

[5] L. G. Li, "Higher education talent cultivation mode in the era of industry 4. 0,” Tsinghua Journal of Education, vol. 37, pp. 6-15, 2016.

[6] B. Johannisson, "University training for entrepreneurship: A Swedish approach,” Entrepreneurship and Regional Development, vol. 3 pp. 6782, 1991. 